\title{
Diatom response to oceanographic and climatic changes in the Congo fan area, equatorial Atlantic Ocean, during the last 190ka BP
}

\author{
Hatin T. ${ }^{1,}{ }^{*}$, Crosta X. ${ }^{2}$, Le Hérissé A. ${ }^{1}$, Droz L. ${ }^{3}$, Marsset Tania ${ }^{4}$
}

${ }^{1}$ Université Européenne de Bretagne, Université de Brest, CNRS, UMR 6538 Domaines Océaniques, Institut Universitaire Européen de la Mer, 6 Avenue Le Gorgeu, 29238, Brest Cedex 3, France

${ }^{2}$ EPOC, Environnements et Paléoenvironnements Océaniques et Continentaux, UMR5805, UMR-

CNRS/INSU, Université Bordeaux 1, Talence Cedex, France

${ }^{3}$ Université Européenne de Bretagne, Université de Brest, CNRS, UMR 6538 Domaines Océaniques, Institut Universitaire Européen de la Mer, Place Nicolas Copernic, 29280, Plouzané, France

${ }^{4}$ Ifremer, Laboratoire Environnements Sédimentaires, B.P. 70, 29280, Plouzané, France

*Corresponding author : T. Hatin, email address : Tristan.Hatin@univ-brest.fr

\begin{abstract}
:
Changes in siliceous productivity in the eastern Equatorial Atlantic Ocean, off the Western African margin, over the last several glacial cycles have been either related to global-to-regional oceanographic changes (upwelling intensity) or climate changes (precipitation and river discharge). Based on diatom assemblages in core KZAI-02, located to the south of the mouth of the Congo River, integrated with a selection of geochemical proxies, we show that siliceous productivity in the southeastern Angola Basin responded to non-linear interactions between both oceanographic and climate changes over the last 190,000 years. High diatom accumulation rates were recorded in the middle part of MIS 6, in cold substage MIS $5 \mathrm{~d}$ and in MIS 3-2. During these intervals, high diatom productivity was sustained essentially by nutrients, including dissolved silica, injected by the Congo River into the ocean. The highest productivity was observed during MIS 3, when nutrients were sourced both from the river and regional upwelling. Low diatom accumulation rates were recorded during early and late MIS 6 , MIS 5e, early MIS 4 and during the Holocene. These resulted either from low river discharge and overall low nutrient stocks in the Angola Basin (despite evidence for upwelling) or from extremely high river discharge. In the case of the latter, the terrigenous load drastically increased the turbidity of the surface waters in the southeastern Angola Basin and lowered phytoplankton productivity despite the presence of sufficient dissolved silica
\end{abstract}




\section{Highlights}

- Siliceous productivity resulted from complex combinations of climatic and oceanic forcing DSi input from the Congo River is essential for high diatom productivity. Highest Congo River discharge had a negative impact on diatom productivity. I I isn't possible using freshwater diatoms to track River discharge evolutions.

Keywords : Diatoms, Productivity, Late quaternary, Millennial time scale, Congo fan area

\section{Introduction}

The Congo deep-sea fan, located in the eastern tropical Atlantic off the western African margin, represents one of the greatest submarine depocenters of the world in the Cenozoic (Savoye et al., 2009). Sedimentation in the region, geochemical budgets and the biological response to environmental changes in both the open ocean waters and the underlying sediments are all strongly influenced by fluctuations in discharges of the Congo River and by the West African monsoon (Cadée, 1978; Schneider et al., 1997; Uliana et al., 2002; Hopkins et al., 2013). A significant volume of sediments, estimated between 30 and 40 million metric tons per year (Jansen, 1990), is exported to the Angola Basin. Three major sources of fan material can be distinguished: (1) dissolved and suspended supply from the Congo River consisting of products of weathering of the West African continental hinterland and river phytoplankton productivity, (2) atmospheric dust and (3) microorganism remains (Jansen, 1990). The sediments of the deep-sea fan system are therefore an important source of information for reconstructing the geological history of the margin (Savoye et al., 2009), the conditions on the continent (Gingele 
et al., 1998; Jahns et al., 1996; Dalibard et al., 2014), the relationship between atmospheric and oceanographic circulation (Schneider et al., 1994; Dupont et al., 1999), the interactions between the Congo River and the tropical Southern Atlantic circulation (Jansen and van Iperen, 1991; Uliana et al., 2002) as well as the variations of primary productivity on the Congo-Angola margin (Schneider et al., 1997; Dale et al., 2002; Marret et al., 2008, 2013; Hardy et al., 2016).

Surface waters in subtropical and tropical areas generally show silicic acid (DSi) concentrations lower than $1 \mu \mathrm{mol} \mathrm{l}^{-1}$, with the exception of coastal nutrient-rich upwelling regions (Nelson et al., 1995). These oligotrophic waters are usually diatom poor. However, in our study area, the Congo River (21 $\mathrm{Mt} \mathrm{SiO}_{2} \mathrm{yr}^{-1}$ or 0.35 teramoles $\mathrm{Si}^{-1}$ ) contributes to a 5 to $10 \mu \mathrm{mol} 1^{-1}$ increase of the silicic acid concentration along the $1000 \mathrm{~km}$ coastline from its mouth to the coast of Cameroon, extending the silica supply from the Benguela upwelling system, which promotes the production of siliceous organisms (50 to $\left.80 \mathrm{~g} \mathrm{SiO}_{2} \mathrm{~m}^{-2} \mathrm{yr}^{-1}\right)$, mainly dominated by diatoms (Schneider et al., 1997). This significant production leads to an increase in the accumulation rates of diatoms in the sediments of the Congo deep-sea fan (Mikkelsen et al., 1984; van Iperen et al., 1987; Uliana et al., 2001) and, therefore, to better preservation, by DSi saturation, of the sediment pore waters (Pokras, 1986). Furthermore, opal preservation in the Congo deep-sea fan also responds to the trace element chemistry of the surface layer of the oceans. Because sediments in the area studied are enriched in Al (Sholkovitz, 1978) and because Al can replace Si within diatom frustules (van Capellen and Qiu, 1997), diatom frustules may be more dissolution resistant (van Bennekom et al., 1989). The combination of these processes may explain why the opal concentrations in sediments encountered in the Congo fan area are 2 to 10 times higher than outside the influence of the fan (Schneider et al., 1997).

Previous studies have shown that diatom accumulation rate and preservation in the deep-sea fan sediments have changed over the two last climatic cycles, and were related to changes in DSi concentrations in the Angola Basin (Mikkelsen et al., 1984; Gasse et al., 1989; Jansen and van Iperen, 1991; Schneider et al., 1997; Uliana et al., 2001). More precisely, Schneider et al. (1997) showed a maximum of buried opal in the south part of the Congo deep-sea fan occurred during humid climate periods. These authors related these maxima to higher siliceous marine 
productivity as the result of additional supply of DSi from the Congo River. Conversely, Mikkelsen et al. (1984) and Uliana et al. (2001, 2002) showed that maxima in diatom production and burial north of the Congo River mouth occurred during cold and dry glacial conditions during stronger upwelling conditions. This difference may be related both to the localization and resolution of the different records and the use of different proxies such as biogenic silica concentrations and diatoms assemblages. However, according to Hopkins et al. (2013), the present response of primary productivity off the Congo River mouth is due to a complex interaction between several mechanisms including coastal/oceanic upwelling and river discharge. In a more synoptic view along the southwest African coast, Crosta et al. (2012) reported that diatoms and biogenic silica productivity were highest in the Guinean Basin outside the influence of upwelling during periods of stronger local river discharge that introduced high amounts of DSi while Romero et al. (2015) suggested that siliceous productivity on the Benguela upwelling system (BUS) along the Namibian coast was essentially controlled by the upwelling intensity, which is mainly forced by trade winds strength.

To better understand the different processes that influence regional diatom productivity, we have conducted a new micropaleontological analysis of diatom assemblages (both marine and freshwater/brackish) from core KZAI-02 (6 $\left.24.20^{\circ} \mathrm{S} / 9^{\circ} 54.10^{\prime} \mathrm{E}\right)$ and have compared these new results to a suite of independent sedimentological and geochemical proxy records extracted from core KZAI-02 and the nearby core GeoB1008-3. Core KZAI-02, drilled $248 \mathrm{~km}$ southwest off the Congo River mouth, was situated in the hemipelagic drape during the active period of the axial fan (Savoye et al., 2009). Our study aims to bring addition information on diatom productivity off the Congo River mouth over the past 190,000 years BP (190 ka BP) and to document its climatic and oceanographic forcings. We analyse the antagonist or synergic impacts of the coastal/oceanic upwelling and the river discharge, the latter bringing nutrients (positive impact) and terrigenous particles (negative impact) to surface waters off the Congo River.

\section{Regional settings}


Present climatic and oceanographic seasonal to inter-annual variations in the equatorial Atlantic Ocean are mainly controlled by the latitudinal migration of the Intertropical Convergence Zone (ITCZ), directly connected to seasonal variations of the trade winds regime (Eriksen and Katz, 1987).

Surface and subsurface water circulation in the Congo deep-Sea Fan is controlled by two major currents (Figure 1A). The first, the Angola current (AC), is mainly fed by the South Equatorial Counter Current (SECC), that transports warm, saline, low nutrient water to the southeast between 5 and $14^{\circ} \mathrm{S}$. The second, the Benguela Current (BC), is characterized by cold, nutrient-rich waters, flowing northward over the Walvis Ridge. Between 24 to $30^{\circ} \mathrm{S}$, the $\mathrm{BC}$ splits into two branches, the Benguela Oceanic Current (BOC) that migrates to the Northwest before joining the South Equatorial Current (SEC), and the Benguela Coastal Current (BCC) that flows along the coast.

Between 14 and $17^{\circ} \mathrm{S}$, the $\mathrm{AC}$ and $\mathrm{BCC}$ converge to form the Angola-Benguela Front $(\mathrm{ABF})($ Figure 1A), characterized by a large gradient in sea-surface temperature (SST), which separates low productivity waters to the north from high productivity waters to the south (Shannon et al., 1986). This front migrates from its northernmost location at $\sim 14^{\circ} \mathrm{S}$ in austral summer to $\sim 16^{\circ} \mathrm{S}$ during austral winter (Meeuwis and Lutjeharms, 1990), depending upon the seasonal intensity of the $\mathrm{AC}$ and $\mathrm{BCC}$, which are themselves directly related to changes in the seasonal atmospheric circulation (Shannon and Nelson, 1996). The complex interaction of AC, SECC and $\mathrm{BC}$ between 5 and $15^{\circ} \mathrm{S}$ leads to the formation of a gyre known as the Angola Dome (AD) (Meeuwis and Lutjeharms, 1990) (Figure 1A).

This gyre pumps sub-surface waters upwards to form a seasonal oceanic upwelling with nutrient-rich waters into the photic zone. Additionally, two seasonal coastal upwelling cells have been observed just south and north of the Congo River mouth at 5 and $7^{\circ} \mathrm{S}$ (Lutjeharms and Meeuwis, 1987). They are considered to be the result of the rising to the euphotic zone of the eastward-flowing equatorial undercurrents (EUC) when they reach the West African Margin (Voituriez and Herbland, 1981; Servain et al., 1982). 
The water composition of the Angola Basin is also greatly influenced by the freshwater discharges of the Congo River, showing two maxima during the year associated with monsoonal circulation and precipitation directly linked to the ITCZ migrations (Eisma and van Bennekom, 1978; van Bennekom and Berger, 1984; Gasse, 2000). The main maximum occurs in December (average $60.000 \mathrm{~m}^{3} \cdot \mathrm{s}^{-1}$ ) with a secondary maximum in April-May (average $41.000 \mathrm{~m}^{3} \cdot \mathrm{s}^{-1}$ ), while the minimum of discharges occurs in July-August (average $29.000 \mathrm{~m}^{3} \cdot \mathrm{s}^{-1}$ ) (Eisma and van Bennekom, 1978). River discharge, reducing the surface ocean density and carrying a large input of suspended sediment, particulate and dissolved carbon and nutrients has a major impact on the geochemical and biological processes of the Angola Basin (Cadée, 1978; Vangriesheim et al., 2009; Hopkins et al., 2013). The most significant freshwater discharges in the ocean are detectable by the presence of a plume of turbid brackish water (salinity $<30 \mathrm{psu}$ ), up to $800 \mathrm{~km}$ off the coast during the austral summer (June-August) (van Bennekom and Berger, 1984; Hopkins et al., 2013). This plume, classified as surface-advected (Yankovsky and Chapman, 1997), forms an isothermal layer with strong salinity stratification between the top of the thermocline and the bottom mixed layer, termed the Barrier layer (Sprintall and Tomczak, 1992).

This phenomenon, especially during the strongest Congo River discharges (Materia et al., 2012), inhibits vertical mixing and could result in the formation of warmer SST and weakest primary productivity (Materia et al., 2012; Hopkins et al., 2013). However, the seasonal to interannual position of the plume, its extent, salinity and thickness (Figure 1B), vary depending on many factors such as ocean currents and wind fields (van Bennekom and Berger, 1984; Denamiel et al., 2013; Hopkins et al., 2013). Minima in the plume surface area occur between May and July (Figure 1B), congruently to maximum southerly wind stress in the area. These conditions lead to shoaling of the thermocline and nitracline across the Angola Basin and limit the Barrier layer effect of the Congo plume, promoting upward flux of nutrients into the euphotic zone and an increase in chlorophyll-a concentrations (Materia et al., 2012; Hopkins et al., 2013). 
In addition to providing large amounts of freshwater, the Congo River brings high concentrations of nutrients to the Angola Basin. Silicate is in excess $(195 \mu \mathrm{mol} / \mathrm{L})$ while nitrate $(9 \mu \mathrm{mol} / \mathrm{L})$ and phosphate concentrations $(0,6 \mu \mathrm{mol} / \mathrm{L})$ are quite low (van Bennekom and Berger, 1984; Vangriesheim et al., 2009; Hugues et al., 2011). These conditions induce high productivity of siliceous phytoplankton in the Angola Basin, mainly as diatoms, which accumulate in the underlying Congo deep-sea fan sediments (van Bennekom and Berger, 1984; Schneider et al., 1997; Uliana et al., 2002; Ragueneau et al., 2009; Raimonet et al., 2015). The diatom phytoplanktonic productivity shows maxima 150-200 km offshore the Congo River mouth, around $11^{\circ} \mathrm{E}$ where the salinity is about 30 psu (Cadée, 1978, 1984). This narrow productive area apparently corresponds to a river induced upwelling, called the "Congo Effect", that is produced by the high velocity of the river water entering in the ocean (Cadée, 1984; Jansen and van Iperen, 1991). Conversely, the minima in productivity have been detected near the River Mouth $(<50 \mathrm{~km})$ where extremely high concentrations of suspended matter reduce light penetration and photosynthesis (Cadée, 1978; Pak et al., 1984).

\section{Material and Methods}

\subsection{Stratigraphy}

Piston core KZAI-02 (6 $\left.24.20^{\prime} \mathrm{S}, 9^{\circ} 54.10^{\prime} \mathrm{E}\right)$ was collected $248 \mathrm{~km}$ off the Congo River mouth at a water depth of $3417 \mathrm{~m}$ during the Zaiango cruise on the R/V Atalante in 2001 (Figure 1B). This 18.20 meters long core is composed of brown-green hemipelagic muds, rich in diatoms, radiolarians and sponge spicules, deposited in the Congo deep-sea fan after cessation of activity of the South edifice around $210 \mathrm{ka}$ ago (Savoye et al., 2009).

Stable oxygen isotopes and radiocarbon ages have only been measured on the top $2 \mathrm{~m}$ of the core where carbonate preservation was adequate. Below this depth, the core chronology is based on the fine tuning of the KZAI-02 total organic carbon (TOC) record with the TOC record of the nearby GeoB1008-3 (6³5.6'S, 10¹9.1'E) (Schneider et al., 1994). The GeoB1008-3 age 
model was originally achieved by tuning its $\delta^{18} \mathrm{O}_{\text {G.ruber }}$ record to the SPECMAP reference curve (Schneider et al., 1994). The core GeoB1008-3 age model was updated by tuning its $\delta{ }^{18} \mathrm{O}_{\text {G.ruber }}$ record to LR04 reference curve (Lisiecki \& Raymo, 2005) (Figure 2A, left panel and associated table). The new interpretation allowed identification 16 tie-points and to provide a $\mathrm{R}^{2}$ of 0.70 . The maximum age difference between the previous and new age models for core GeoB1008-3 is $\sim 10$ ka.

The comparison of the KZAI-02 TOC record to the core GeoB1008-3 TOC record led to the identification of 23 clear tie-points (Figure 2A, right panel and associated table). Core KZAI-02 covers the last 190,000 years before present (ka BP) (Figure 2A). Although the accuracy of core KZAI-02 age model has a margin of error up to a few thousand years, we believe that transitions between glacial and interglacial stages and between stadials and interstadials are evident enough to allow oceanographic interpretations at these timescales. At site KZAI-02, the sedimentation rate varied between $\sim 4$ and $24 \mathrm{~cm} . \mathrm{ka}^{-1}$ with highest values during the interglacial periods MIS 5 , MIS 3 and MIS 1.

\subsection{Diatoms}

In total, 100 samples were collected from core KZAI-02 with a spacing of 10 to $20 \mathrm{~cm}$, giving a 1 to 5 ka resolution with a mean resolution of $\sim 2 \mathrm{ka}$. Extraction of diatoms was carried out on $1 \mathrm{~g}$ of dry sediment from each sample, using hot $\mathrm{H}_{2} \mathrm{O}_{2}$ followed by $\mathrm{HCl}$ to remove organic matter and carbonates, following the protocol explains in Crosta and Koç (2007). Diatom slides were prepared using the method of Rathburn et al. (1997). Identification and counts of diatoms were performed using a Leica microscope at x1000 magnification, and three coverslips per sample were examined following the counting rules described in Crosta \& Koç (2007).

At least 300 valves minimum were counted. Identification of diatoms is based on Sundström (1986), Moreno-Ruiz and Licea (1994), Moreno et al. (1996), Hasle and Syversten (1997), Romero et al. (1999), Rivera et al. (2006) and Sar et al. (2010). Identification of brackish and freshwater diatoms was based on Servant-Vildary (1981), Gasse (1986), Lange and Tiffany (2002) and Sar et al. (2010). Diatoms were identified to species or species group 
level. The relative abundance of each species was calculated as the fraction of number of specimens of each species relative to the total number of diatoms in the sample. Diatom accumulation rates (DAR) were calculated as follows:

$$
\mathrm{DAR}=\left(\mathrm{NV}^{*} \mathrm{WBD} * \mathrm{SR}\right) / 2
$$

where DAR are the diatom accumulation rates in millions of diatoms $\mathrm{cm}^{-2} \mathrm{ka}^{-1}$, Nv the number of valves per gram of dry sediment, WBD the wet bulk density in $\mathrm{g} . \mathrm{cm}^{-3}$ measured on board and SR the sedimentation rates in $\mathrm{cm} . \mathrm{ka}^{-1}$.

\subsection{Ecology of diatoms}

The diatom record in core KZAI-02 is highly diversified with the identification of 80 taxa. Diatom species with well-documented ecological preferences were assigned to one of the following groups: Eutrophe diatoms, Mesotrophe diatoms, Oligotrophe diatoms, Brackish and Freshwater diatoms based on previous investigations on diatom distribution in surface waters and in surface sediments from low latitude environments (e.g., Pokras and Molfino, 1986; van Iperen et al., 1987; Jansen \& van Iperen, 1991; Hasle \& Syvertsen, 1997, Romero et al., 1999, 2002, 2005, 2011, 2012; Crosta et al., 2012). In core KZAI-02, the sum of these five ecological groups represents more than $95 \%$ of the total diatom assemblage. The composition of each ecological groups is detailed in Table 1 .

Eutrophe diatoms thrive in surface waters with high dissolved silica concentrations and/or high rate of nutrient replenishment to sustain blooming conditions. In our area, this group is dominated by Chaetoceros (Hyalochaete) resting spores (noted hereafter CRS) and Thalassionema nitzschioides var. nitzschioides (Table 1). The occurrence of CRS can be attributed to seasonal variability of coastal upwelling and nutrient input from the river outflow

(the Congo effect) (Cadée, 1984; Jansen \& van Iperen, 1991), while Thalassionema nitzschioides spp. are mostly abundant in areas of coastal or front filament upwelling (Romero et al., 1999; Jansen \& van Iperen, 1991).

Mesotrophe diatoms live in nutrient-rich coastal marine environments but, generally, out of upwelling cells. This group, which tracks high dissolved silica levels, higher siliceous 
productivity but low turbulence waters (no upwelling condition), is here composed of large and highly silicified centric diatoms such as Actinocyclus spp., Actinoptychus spp., Coscinodiscus spp., and the pennate diatom Fragilariopsis doliolus (Table 1).

Oligotrophe diatoms thrive in warm, nutrient-poor surface waters with low siliceous productivity. This group is here dominated by large and well silicified centric diatoms such as Azpeitia spp., Planktoniella sol, Pseudosolenia calcar-avis, Rhizosolenia spp., and Thalassiosira spp (Table 1).

Brackish diatoms live generally in neritic environments with highly variable salinities. In our area, this group is related to the Congo River plume (Van Iperen et al., 1987). This group is mainly composed by centric diatoms such as Cyclotella litoralis and C. striata (Table 1).

The occurrence of Freshwater diatoms in oceanic sediments could result from fluvial transport, turbidity current or eolian transport. In our area, we consider the Congo River as the main vector for the deposition of freshwater diatoms in the deep-sea fan sediments as suggested in the literature (Melia, 1984; Gasse et al., 1989; van Iperen et al., 1987; Jansen and van Iperen, 1991, Uliana et al., 2001). This group is here dominated by Aulacoseira spp., Cyclotella meneghiniana, Stephanodiscus astrea, Fragilaria spp. and Navicula spp (Table 1).

\subsection{Bulk geochemistry}

The total organic carbon (TOC) content was obtained with an IR analyzer LECO-212. Assuming that all carbonates are pure calcite, or aragonite, the sedimentary TOC content was calculated as the difference between the total carbon and the carbonate content. The precision of calcium carbonate and total carbon analyses are $\pm 0.5 \%$ and $\pm 0.1 \%$, respectively. Analyses were performed with a mean resolution of $10 \mathrm{~cm}$ (Dalibard et al., 2014) and a temporal resolution of $1 \mathrm{ka}$.

X-ray fluorescence spectroscopy (XRF) was used to determine the quantitative elemental composition of the sediment core. Core KZAI-02 was analyzed at a $1 \mathrm{~mm}$ resolution, and a temporal resolution of less than $1 \mathrm{ka}$, with the Avaatech XRF core-scanner at IFREMER in 
Brest, France. These data have been obtained on half sections of the core with different energy levels sets $(10 \mathrm{kv}$ and $30 \mathrm{kv})$, allowing detection of the elements from aluminium (Al) to lead $(\mathrm{Pb})$. Several elemental ratios such as aluminum to potassium $(\mathrm{Al} / \mathrm{K})$ and iron to titanium (Fe/Ti) that are sensitive to changes in climatic conditions (Schneider et al., 1997; Zabel et al., 2001; Croudace et al., 2006; Cuven et al., 2010; Itambi et al., 2010; Govin et al., 2012) are used in the following account.

\section{Results}

\subsection{Diatom concentrations and accumulations rates}

Total marine diatom abundances $\left(\mathrm{ABS}_{\mathrm{m}}\right)$ and diatom accumulation rates $\left(\mathrm{DAR}_{\mathrm{m}}\right)$ show the same down-core patterns in KZAI-02 (Figure 3A). DAR $\mathrm{m}_{\mathrm{m}}$ varying between $\sim 1,8 \times 10^{6}$ and $600 \mathrm{x}$ $10^{6}$ diatoms $\mathrm{cm}^{-2} \mathrm{ka}^{-1}$ (average of $\sim 160 \times 10^{6}$ diatoms $\mathrm{cm}^{-2} \mathrm{ka}^{-1}$ ) (Figure 3A). DAR $\mathrm{m}$ shows highest values ( $>300 \times 10^{6}$ diatoms $\mathrm{cm}^{-2} \mathrm{ka}^{-1}$ ) during the major part of the glacial MIS 6 , from 175 to $145 \mathrm{ka}$ BP and the MIS 3 between 48 and $28 \mathrm{ka}$ BP. Intermediate DAR values, comprised between 100 and $30010^{6}$ diatoms $\mathrm{cm}^{-2} \mathrm{ka}^{-1}$, are found during most of the MIS 5 and MIS 2 with peak values centered on 115 and $82 \mathrm{ka} \mathrm{BP}$. Low $\mathrm{DAR}_{\mathrm{m}}$ values $\left(<100 \times 10^{6}\right.$ diatoms $\mathrm{cm}^{-2} \mathrm{ka}^{-1}$ ) are observed at the beginning of MIS 6 between 190 and $176 \mathrm{ka}$ BP and between 170 and $163 \mathrm{ka} \mathrm{BP}$. Low values are measured in the first part of MIS 4 at around $70 \mathrm{ka} \mathrm{BP}$. The lowest values registered in KZAI-02 concern the interval 140 to $115 \mathrm{ka} \mathrm{BP}$, across the late MIS 6 and the early MIS 5, and since $14 \mathrm{ka} \mathrm{BP.} \mathrm{Accumulation} \mathrm{rates} \mathrm{(AR)} \mathrm{of} \mathrm{the} \mathrm{different} \mathrm{marine}$ diatom groups show the same trends as the $\mathrm{DAR}_{\mathrm{m}}$, but with episodic differences in the amplitude of the variations. The best example is provided by the two most abundant diatom species and species groups in the core, T. nitzschioides var nitzschioides and CRS, both belonging to the Eutrophe diatom group. A double-peak is observed for T. nitzschioides var nitzschioides during MIS 6 with a maximum abundance and AR at $160 \mathrm{ka}$ BP (Figure 3B). Conversely, CRS abundances and AR are at their highest at about $172 \mathrm{ka}$ and the second peak at 
$160 \mathrm{ka} \mathrm{BP}$ is damped (Figure 3B). Similarly, the T. nitzschioides var nitzschioides AR record mimics the $\mathrm{DAR}_{\mathrm{m}}$ record during MIS 4-1 while the CRS AR record is again damped during MIS 3. For the last $190 \mathrm{ka} \mathrm{BP,} \mathrm{the} \mathrm{Mesotrophe} \mathrm{and} \mathrm{Oligotrophe} \mathrm{diatom} \mathrm{groups} \mathrm{showed} \mathrm{low} \mathrm{AR}$ values $\left(<10 \times 10^{6}\right.$ diatoms $\left.\mathrm{cm}^{-2} \mathrm{ka}^{-1}\right)$, except between 175 to $168 \mathrm{ka} \mathrm{BP}$ and at $82 \mathrm{ka} \mathrm{BP}$ where the values increased abruptly $\left(>90 \times 10^{6}\right.$ diatoms $\left.\mathrm{cm}^{-2} \mathrm{ka}^{-1}\right)$ (Figure 3D, E). The down-core AR record of the Brackish diatom group shows its highest values between $115 \mathrm{ka} \mathrm{BP}$ and $80 \mathrm{ka}$ BP, with two major peaks centered on $112 \mathrm{ka} \mathrm{BP}$ and $85 \mathrm{ka} \mathrm{BP}$ (Figure 3F). This group also presents high AR during the MIS 3 and MIS 2 from $55 \mathrm{ka} \mathrm{BP}$ to $16 \mathrm{ka} \mathrm{BP}$, with its highest values at 35 ka BP $\left(>300 \times 10^{6}\right.$ diatoms $\left.\mathrm{cm}^{-2} \mathrm{ka}^{-1}\right)$. The AR record of the Freshwater diatoms $\left(\mathrm{DAR}_{\mathrm{fw}}\right)$ is different from all other diatom groups (Figure $3 \mathrm{G})$. The highest $\mathrm{DAR}_{\mathrm{fw}}\left(>30 \times 10^{6}\right.$ diatoms cm$^{-2}$ $\mathrm{ka}^{-1}$ ) were observed at $175 \mathrm{ka} \mathrm{BP}, 115,80-75,57$ and $46 \mathrm{ka} \mathrm{BP}$.

\subsection{Relative abundance of diatoms}

The relative contribution of each group of diatoms to the total assemblage is depicted in Figure 4. At the beginning of MIS 6, between 190 and $180 \mathrm{ka} \mathrm{BP}$, the Brackish diatoms are dominant, representing up to $50 \%$ of the assemblages (Figure 4E). This group is replaced by $T$. nitzschioides var nitzschioides during the mid MIS 6, between 180 to $140 \mathrm{ka}$ BP (Figure 4A). During this interval, CRS represents the second most abundant diatom group with a maximum contribution of $20 \%$. The composition of the diatom assemblage changed clearly between 140 ka BP and $125 \mathrm{ka} \mathrm{BP,} \mathrm{across} \mathrm{the} \mathrm{late} \mathrm{MIS} 6$ and early MIS 5, when T. nitzschioides var nitzschioides (Figure 4A) was replaced by Oligotrophe diatoms (Figure 4D), CRS (Figure 4B) and Freshwater diatoms (Figure 4F). During this interval, the overall preservation of diatom assemblages is very poor. Between $125 \mathrm{ka} \mathrm{BP}$ and $115 \mathrm{ka} \mathrm{BP,} \mathrm{T.} \mathrm{nitzschioides} \mathrm{var} \mathrm{nitzschioides,}$ Mesotrophe and Freshwater diatoms increased at the expense of CRS and Oligotrophe diatoms. Between $115 \mathrm{ka} \mathrm{BP}$ and $82 \mathrm{ka}$ BP (from MIS $5 \mathrm{~d}$ to the base of MIS 5a) the assemblages were dominated by Brackish diatoms with maximum relative abundances over $60 \%$ between $115 \mathrm{ka}$ $\mathrm{BP}$ and $105 \mathrm{ka}$ BP and between $88 \mathrm{ka} \mathrm{BP}$ and $82 \mathrm{ka}$ BP (Figure 4E). Freshwater diatoms 
represent the second most abundant group during this interval. Brackish diatoms abruptly decreased between $82 \mathrm{ka} \mathrm{BP}$ and $80 \mathrm{ka}$ BP. Until $57 \mathrm{ka} \mathrm{BP}$, the diatom assemblage was dominated by the Eutrophe diatoms ( $\sim 60 \%)$, Mesotrophe diatoms ( $\sim 10 \%)$, Oligotrophe diatoms $(\sim 10 \%)$ and Freshwater diatoms ( 10\%) (Figure 4). During the $56 \mathrm{ka}$ BP to $20 \mathrm{ka}$ BP period, the diatom assemblages were dominated by Eutrophe diatoms $(\sim 70 \%)$ and Brackish diatoms ( 20\%). During the last $15 \mathrm{ka}$ BP a sharp drop occurred for T. nitzschioides var. nitzschioides and Brackish diatoms relative abundance while an increase in Freshwater diatoms $(\sim 30 \%)$, in CRS ( 20\%), in Oligotrophe diatoms ( $\sim 15 \%)$ and in Mesotrophe diatoms $(\sim 5 \%)$ is recorded.

\subsection{Geochemical proxies}

The $\mathrm{Al} / \mathrm{K}$ ratio shows highest values $(>0.3)$ during two intervals of MIS 6 (175-168 and 160-140 ka BP). Others high values are recorded during interstadial 5e, 5c and 5a of MIS 5 and the entire duration of MIS 1 . The lowest values $(<0.2)$ are observed during three intervals of MIS 6 (190-180, 168-160 and 145-130 ka BP), and during interstadials 5d and 5b from MIS 5. Except for some peak values (>0.3) at the end of MIS 4 and in the middle of MIS 3 (from 50 to $45 \mathrm{ka} \mathrm{BP})$, the $\mathrm{Al} / \mathrm{K}$ ratio show no significant variations from MIS 4 to the MIS 2 - MIS 1 transition (Termination I). Of interest are the large variations and oscillations of the $\mathrm{Al} / \mathrm{K}$ ratios during the last $190 \mathrm{ka} \mathrm{BP}$, superimposed on a generally decreasing trend (Figure 5A). The $\mathrm{Fe} / \mathrm{Ti}$ ratio record show higher values $(>0.1)$ during interstadials $5 \mathrm{e}, 5 \mathrm{c}$ and $5 \mathrm{a}$ of MIS 5 and the late Holocene (Figure 5B).

\section{Discussion}

Our new diatom record from the Congo deep-sea fan yields additional information to better constrain the factors that have influenced diatom productivity in the Angola Basin over the last 190 ka BP. Both high productivity and low productivity intervals are observed during glacial and interglacial phases, and variations do not follow a precessional cycle typical of low latitude environments, highlighted by the monsoon index established by Caley et al., (2010) (Figure. 6). 
Therefore, we suggest that pluri-millennial variations of diatoms accumulation rate and the diatom assemblages resulted from the combination of different climate and oceanic processes. As a consequence of this discovery, we focus on periods of high diatom productivity (part 5.1) and periods of low diatom productivity (part 5.2), and infer for each period the interactions between oceanic (upwelling, location of the $\mathrm{ABF}$ ) and climate (precipitation and subsequent river discharge).

\subsection{High diatom productivity periods}

Cold and dry conditions generally prevailed during MIS 6 , because of the enhanced intensity of southeast trade winds over equatorial Africa (Flores et al., 2000; Shi et al., 2001; Zabel et al., 2001; Stuut et al., 2002). However, several periods within this glacial stage experienced warmer and more humid conditions in relation to the intensification of the African Monsoon (Jahns et al., 1996; Caley et al., 2011) (Figure 6D). More humid conditions over the Congo Basin resulted in strong chemical weathering, traced by higher values of the $\mathrm{Al} / \mathrm{K}$ ratio, e.g between 175 and $168 \mathrm{ka} \mathrm{BP}$ and between 160 and $145 \mathrm{ka}$ BP (Figure 6D). These higher values of $\mathrm{Al} / \mathrm{K}$ ratio correspond to our highest $\mathrm{DAR}_{\mathrm{m}}$ values (Figure $6 \mathrm{H}$ ). Among the diatoms, both T. nitzschioides var nitzschioides and CRS are well represented during these periods (Figure 6F). These fast bloomers are known to thrive in turbulent eutrophe waters characterized by high DSi concentrations (Hasle and Mendiola,1967; Sancetta, 1982; Schuette and Schrader, 1981; Abrantes, 1988; Romero et al., 2011), and are preferentially found in coastal and oceanic upwelling cells in the Angola Basin (van Iperen et al., 1987; Abrantes et al., 2003; Romero, 2010).

High abundances of CRS in sediments of the Congo deep sea fan were also related to the river induced upwelling, the so called "Congo Effect" that pumps upward subsurface waters (Jansen and van Iperen, 1991). During the 175-145 ka BP period, Freshwater diatoms represent the second most abundant group (Figure 4F). Taken together, these pieces of evidence support the argument for higher Congo River discharges in periods of high precipitation, which led to 
the injection of DSi in regional surface waters directly via the river discharge and indirectly via the river induced upwelling. However, the low contribution of Brackish diatoms suggests that the Congo Plume, characterised by low salinity and turbid waters, was not present over the core site. Two different processes, possibly acting together, can explain this. Firstly, the major drop of sea level (110 m) during MIS 6 (Giresse, 1981), may have displaced the Congo River mouth closer to the core site, with the plume then extending seaward. As a consequence of this, the deep incision of the Angola Margin by the Congo Canyon, directly connected with the Congo River mouth (Savoye et al., 2009), may have also permitted the access of the oceanic waters into the estuary, thus damping the impact of the Congo Effect. Secondly, a southward migration of the ABF well beyond KZAI-02 core site during MIS 6 (Jansen et al., 1996) (Figure 6A), could have intensified the Angola Current (AC) and pushed the Congo Plume towards the south.

The MIS 5 was characterized by strong variations of monsoon intensity (Caley et al., 2011) and associated precipitation (Figure 6D), a general northward migration of the ABF (Figure 6A; Jansen et al., 1996) and weak trade wind intensity (Abrantes et al., 2003). During the MIS 5, diatom productivity displays two maxima. The first one during the cooler interstadial $5 \mathrm{~d}$ and the second during the warmer interstadial 5a (Figure 6H). During the MIS 5d, 115-110 ka BP, the diatom assemblage was dominated by the Freshwater and Brackish diatom groups (Figure 6G) with the accompanying presence of Mesotrophe diatoms (Figure 4C). Thalassionema nitzschioides var nitzschioides and CRS were almost absent (Figure 6F). This period was characterized by a low monsoon index and low precipitation (Figure 6D). The congruent high representation of Afromontane forest biome (Figure 6B), mainly composed of pollen of Podocarpus, easily dispersed by wind, reflected the influence of stronger trade winds and aridity (Dalibard et al., 2014), while the ABF was starting to migrate towards the north (Figure 6A). We suggest that these conditions favoured the expansion of the brackish plume until it reached our core site, leading to the development of the Brackish diatom. Conversely, during the MIS 5a, 82-75 ka BP, climatic conditions were characterized by a high monsoon index and high precipitation (Figure 6D), an expansion of the rain forest (Figure 6C), a 
northward position of the ABF (Figure 6A) and high SST (Figure 6A). Overall, this evidence suggests the presence of the Congo River plume over the core site, allowing for the development of Brackish diatoms and the transport of Freshwater diatoms. These diatoms did not use all the DSi stock injected by the river flow, which allowed Mesotrophe and Oligotrophe diatoms (Figures 3D,E and Figure 4C,D) to develop later, probably when the turbid plume faded.

During the MIS 3, highest $\mathrm{DAR}_{\mathrm{m}}$ and $\mathrm{BSi}$ values result from the co-occurrence of Eutrophe and Brackish diatoms (Figure 6F,G). This stage showed particular conditions, with strong oceanic circulation under a regime of rather weak atmospheric conditions (Dupont et al., 1999). Low extension of the tropical rainforest (Figure 6C) indicates that the MIS 3 was globally cold and dry (Dalibard et al., 2014), here confirmed by low Al/K values (Figure 6D). During this interval, the stronger advection of the Benguela current, with a northward ABF position (Figure 6A) favoured the supply of significant amounts of cold (Figure 6A) nutrients rich waters (Figure 6B) in the Angola Basin. Even if the Benguela Current did not penetrate our core area (Schneider et al., 1995), its intensification during MIS 3 favoured the transport of eddies of upwelled waters associated with the Angola Dome (Jansen et al., 1996). We propose that the combination of these oceanic and atmospheric conditions, together with low sea level, resulted in the presence of a small and shallow Congo River plume over the core site. This plume was not large or turbid enough to prevent oceanic diatoms using the DSi injected into surface waters by the river discharge and the oceanic upwelling. We suggest that these conditions, characterized by large input of both river and oceanic nutrients in the Angola Basin waters, are optimal for diatom productivity in our area.

Climatic conditions during the MIS 2 were characterized by a weaker African monsoon, less precipitation and stronger atmospheric circulation than during MIS 3 (Schneider et al., 1994; Caley et al., 2011; Dalibard et al., 2014). The ABF migrated to the south back to its MIS 5 latitudinal mean position. The higher occurrence of upwelling-related diatoms indicates that stronger trade winds, and lower sea level (Figure 6E), promoted upwelling conditions bringing 
oceanic nutrients to the surface waters of the Angola Basin. The general decrease in $\mathrm{DAR}_{\mathrm{m}}$ values could be explained by low river discharge and DSi injection (Figure 6D) in the Angola Basin. Conversely, higher concentration of oceanic nutrients, provided by increased upwelling conditions, favoured the development of other phytoplankton organisms like dinoflagellates (Dupont et al., 1999; Marret et al., 2001), accounting for the decoupling between BSi and TOC (Figure 6H,B).

\subsection{Low productivity periods}

During the early MIS 6, precipitation was reduced because of a weak African monsoon (Figure 6C,D) and air-temperatures were generally low (Dalibard et al., 2014) in our study area (Figure 6B). The $\mathrm{ABF}$ was located to the south (Figure 6A). Our data suggest that these cold and dry conditions resulted in weak chemical weathering and low Congo River discharge, which did not allow for a significant injection of DSi in the Angola Basin. The coastal upwelling, inferred from the low contribution of upwelling-related diatoms, was not strong enough despite intense winds to compensate the weak river sourced DSi. The planktonic production was then probably dominated by non-siliceous organisms as indicated by high TOC content (Figure 6B) but low BSi content (Figure 6H). Comparable climatic and oceanic conditions during the early MIS 4 (72-62 ka BP) may have resulted in a similar response of the diatom community at that time. However, the absence of Brackish diatoms but moderate abundances of Mesotrophe and Oligotrophe diatoms (Figure 4C, D) suggest that the Congo River plume did not reach the core site.

The lowest $\mathrm{DAR}_{\mathrm{m}}$ values are observed during four intervals characterized by totally different climatic and oceanic conditions. Firstly, from 140 to $130 \mathrm{ka}$ BP at the transition between MIS 6 and MIS 5 (Termination II), the few diatoms preserved in core KZAI-02 are mostly from the CRS and Oligotrophe groups along with Freshwater diatoms (Figure 4B,D,F). Climate conditions were characterized by a weak monsoon intensity and weak precipitation (Figure 6C, D). Reduced river discharges and a southern position of the ABF (Figure 6A) did 
not allow injection of DSi in the southern Angola Basin. Rising sea level (Figure 6E) during this interval may have increased the distance between the core site and the river mouth, and could have limited nutrient input to our core area. Surface water productivity was then dominated by non-siliceous organisms as shown by the decoupling between TOC (Figure 6B) and BSi content (Figure $6 \mathrm{H}$ ). Additionally, low productivity and low export of diatoms could have resulted in DSi under-saturated waters enhancing the dissolution of the diatom valves at the sediment water interface (Pokras, 1986; Ragueneau et al., 2000). As such, only highly silicified diatom taxa, like CRS and the Oligotrophe group of Rhizosolenia spp. were preserved.

In line with this period of low productivity, lowest $\mathrm{DAR}_{\mathrm{m}}$ intervals occurred during the warm substage MIS 5e. During this period, the diatom assemblages were dominated by resistant dissolution taxa such as the Freshwater species Aulacoseira granulata and the Eutrophe CRS (Figure 4A, C, E). This interval were characterized by the strongest African monsoon and highest precipitation of the last $190 \mathrm{ka}$ (Gasse et al. 1989; Uliana et al., 2002; Caley et al., 2011) (Figure 6C, D), thus promoting highest river discharge. Weak trade winds during African monsoon maxima (Schneider et al., 1994) prevented the occurrence of the coastal upwelling which, combined with high sea level, favored a maximal expansion of the Congo plume. These conditions favored the formation of a warm (Figure 6A), turbid (Figure 5B) layer over our core site. Highest $\mathrm{Fe} / \mathrm{Ti}$ (Figure 5B) values and sedimentation rate (Figure 2B) during this interval in core KZAI-02 indicate more terrigenous input (Itambi et al., 2010), linked to an intensification of Congo river discharges. We propose that the plume was turbid enough to reduce light penetration and prevent photosynthesis taking place (Figure 6B,H) (Cadée, 1978; Pak et al., 1984). As such, only strongly silicified diatoms transported by the river flow were preserved in the sediments during episodes of maximum river discharge. Associated with the huge river discharge, export and accumulation of terrigenous materiel into the Congo deep sea fan may have favored the dilution and mechanical breakage of the diatom valves. A similar situation has been described in Quaternary sediments in the Amazon deep-sea fan (Mikkelsen, 1997). This huge river, characterized by 20 times higher export of suspended material than the Congo River (Coynel et al., 2005), shows less optimal conditions for siliceous productivity and biogenic 
silica preservation in the sediments because of high terrestrial input (Conley, 1997). We suggest that similar conditions prevailed in the proximal part of the Congo deep-sea fan during strongest Congo River discharges during MIS 5e and MIS 1.

\subsection{The continental signal}

The presence of freshwater diatoms in the Congo deep-sea fan sediments raises the problem of identification of the source area and transport mechanisms. In the nearshore areas, influenced by the Congo river discharge, the fluvial transport is considered as major agent of freshwater diatoms deposition (Gasse et al., 1989; van Iperen et al., 1987; Jansen and van Iperen, 1991; Uliana et al., 2001). For Uliana et al., (2001), higher $\mathrm{DAR}_{\mathrm{fw}}$ values reflect humid periods with increased rainfall and river discharge fostered by an intensified monsoon during times of maximum insolation in the Northern Hemisphere. However, our results show that $\mathrm{DAR}_{\mathrm{fw}}$ values (Figure 6G) does not always correlate with maxima in monsoon intensity and thereof of precipitation and river discharge (Figure 6C,D). This may be explained by the fact that growth and abundance of freshwater diatoms in the Congo River can be limited by several factors, like the availability of nutrients and the water turbidity (Hughes et al., 2011). Deposition at the core site also depends on the position of the river plume which in turn depends on climate and oceanographic conditions. Furthermore, high percentages of freshwater diatoms in sediments, correlated with poor preservation of marine diatom valves, as show during MIS $5 \mathrm{e}$ and MIS 1, may be the result of selective dissolution, as observed in surface sediments (van Iperen et al., 1987) and suggested for downcore assemblages (Uliana et al., 2001). These processes prevent here the use of freshwater diatoms alone to robustly track the Congo River discharge evolutions.

\section{Conclusions}

The analysis of diatom assemblages in core KZAI-02, located in the upper Congo deepsea fan area, has allowed documentation of changes in siliceous productivity in the Angola 
Basin over the last $190 \mathrm{ka}$ BP. Our results suggest that changes in siliceous productivity resulted from a more complex combination of climatic and oceanic processes than previously appreciated. Our findings are:

(1) DSi input from the Congo River is essential for the establishment of high diatom productivity. During periods with clear enhancement of upwelling conditions and low Congo River discharge, the abundance of diatoms was weak (parts of MIS 6, MIS 4), probably because the upwelling did not bring enough DSi to sustain diatom growth. Other phytoplankton were then dominant.

(2) Optimal conditions for diatom growth (MIS 3) resulted from significant river discharge and strong upwelling, along with a northern position of the AngolaBenguela Front (ABF), allowing for the build-up of large nutrient stocks (including DSi) in surface waters of the Angola Basin.

(3) However, the highest Congo River discharge in periods of strong African monsoon (MIS 5e and MIS 1) had a negative impact on diatom productivity. The Congo River plume became extremely turbid and limited light penetration that was then the proximal limiting factor for phytoplankton productivity.

(4) The position, extent and turbidity of the Congo River plume depend on precipitation over the nearby continent, the wind fields, the position of the ABF and the sea level. Similar investigations should be conducted in different parts of the Congo deep-sea fan to establish variations in the Congo River plume and its impact on regional phytoplankton productivity and burial.

(5) It is difficult to interpret the variations of discharges of the Congo river during late Quaternary by studying the $\mathrm{DAR}_{\mathrm{fw}}$ due to the interaction of different factors such as productivity, location of deposition centers and dissolution. 
Abrantes, F., 2003. A 340,000 year continental climate record from tropical Africa: news from opal phytoliths from the equatorial Atlantic. Earth Planet. Sci. Lett. 209, 165-179.

Abrantes, F., 1988. Diatom assemblages as upwelling indicators in surface sediments off Portugal. Mar. Geol. 85(1), 15-39.

Cadée, G.C., 1978. Primary production and chlorophyll in the Zaire river, estuary and plume. Neth. J. Sea Res. 12, 368-381.

Cadée, G.C., 1984. Particulate and dissolved organic carbon and chlorophyll a in the Zaire river, estuary and plume. Neth. J. Sea Res. 17, 426-440.

Caley, T., Malaizé, B., Revel, M., Ducassou, E., Wainer, K., Ibrahim, M., Shoeaib, D., Migeon, S., Marieu, V., 2011. Orbital timing of the indian, East Asian and African boreal monsoons and the concept of a 'global monsoon'. Quat. Sci. Rev. 30, 3705-3715.

Conley, D. J. 1997. Riverine contribution of biogenic silica to the oceanic silica budget. Limnol. Oceanogr. 42, 774-777. doi: 10.4319/1o.1997.42.4.0774 
Coynel, A., Seyler, P., Etcheber, H., Meybeck, M., Orange, D., 2005. Spatial and seasonal dynamics of total suspended sediment and organic carbon species in the Congo River. Glob. Biogeochem. Cycles 19(4). .http://dx.doi.org/10.1029/2004GB002335.

Crosta, X., Koc, N., 2007. Diatoms: From micropaleontology to isotope geochemistry, in Hilaire Marcel, C, and de Vernal, A. (Eds.), Proxies in Late Cenozoic Paleoceanography, Elsevier, Amsterdam, The Netherlands, 327-369.

Crosta, X., Romero, O.E., Schneider, R., Ther, O., 2012. Climatically-controlled siliceous productivity in the eastern Gulf of Guinea during the last 40.000 years. Clim. Past 8, 415-431.

Croudace, I.W., Rindby, A., Rothwell, R.G.. 2006. ITRAX: description and evaluation of a new multi-function X-ray core scanner, p. 51-63. In R. G. Rothwell [ed.], New techniques in sediment core analysis. Geological Society Special Publication.

Cuven, S., Francus, P., Lamoureux, S.F., 2010. Estimation of grain size variability with micro X-ray fluorescence in laminated lacustrine sediments. Cape Bounty, Canadian High Arctic. J. Paleolimnol. 44(3), 803-817.

Dale, B., Dale, A.L., Jansen, J.H.H., 2002. Dinoflagellate cysts as environmental indicators in surface sediments from the Congo deep-sea fan and adjacent regions. Palaeogeogr. Palaeoclimatol. Palaeoecol.185(3-4), 309-338.

Dalibard, M., Popescu, S.-M., Maley, J., Baudin, F., Melinte-Dobrinescu, M.-C., Pittet, B., Marsset, T., Dennielou, B., Droz, L., Suc, J.-P., 2014. High-resolution vegetation history of West Africa during the last 145 ka. Geobios. 47, 183-198. 
Denamiel, C., Budgell, W., Toumi, R., 2013. The Congo River plume: Impact of the forcing on the far-field and near-field dynamics. J. Geophys. Res. 118, 964-989.

Dupont, L., Schneider, R., Schmüser, A., Jahns, S., 1999. Marine-terrestrial interaction of climate changes in West Equatorial Africa of the last 190,000 years. Paleoceanogr. Afr. 26, 6184.

Eisma, D., Van Bennekom, A.J., 1978. The Zaire River and the estuary and the Zaire outflow in the Atlantic Ocean. Neth. J. Sea Res. 12, 255-272.

Eriksen, C. C., Katz, E. J., 1987. Equatorial dynamics. Rev. Geophys. 25(2), 217-226.

Flores, J.-A., Bàrcena, M.A., Sierro, F.J., 2000. Ocean-surface and wind dynamics in the Atlantic Ocean off Northwest Africa during the last 140000 years. Palaeoceanogr. Palaeoclimatol. Palaeoecol. 161, 459-478.

Gasse, F., 1986. East African diatoms: Taxonomy, ecological distribution. Bibliotheca Diatomologica 11, 201 pp., 44 pls.

Gasse, F., Stabell, B., Fourtanier, E., van Iperen, J., 1989. Freshwater diatom influx in intertropical Atlantic: Relationships with continental records from Africa. Quat. Res. 32, 229243.

Gasse., F., 2000. Hydrological changes in the African tropics since the Last Glacial Maximum. Quat. Sci. Rev. 19, 189-211. 
Gingele, F.X., Müller, P.M., Schneider, R.R., 1998. Orbital forcing of freshwater input in the Zaire Fan area: clay mineral evidence from the last 200 kyr. Palaeoceanogr., Palaeoclimatol., Palaeoecol. 138, 17-26.

Giresse, P., Jansen, J.H.F., Kouyoumontzakis, G.,Moguedet, G., 1981. Les fonds du plateau continental congolais et le delta sous-marin du fleuve Congo, in Milieu marin et ressources halieutiques de la République Populaire du Congo, edited by A. Fontana, Tray. Doc. ORSTOM., 138, pp. 13-45.

Govin, A., Holzwarth, U., Heslop, D., Ford Keeling, L., Zabel, M., Mulitza, S., Collins, J. A., Chiessi, C. M., 2012. Distribution of major elements in Atlantic surface sediments (36॰ N 49 。 S): Im print of terrigenous input and continental weathering, Geochem. Geophy. Geosy., 13, Q01013, doi: 10.1029/2011gc003785.

Hardy, W., Penaud, A., Marret, F., Bayon, G., Marsset, T., Droz, L., 2016. Dinocyst assemblage constraints on oceanographic and atmospheric processes in the eastern equatorial Atlantic over the last 44 kyr. Biogeosciences, 13, 4823-4841, doi:10.5194/bg-13-4823-2016.

Hasle, G. R., Syversten, E. E. 1997. Marine diatoms, in Tomas, C.R. (Eds.), Identifying Marine Diatoms and Dinoflagellates, Academic Press, San Diego, USA, 5-385.

Hasle, G.R., de Mendiola, B.R.E., 1967. The fine structure of some Thalassionema and Thalassiothrix species. Phycologia 6(2-3), 107-126, 53 figs.

Hopkins, J., Lucas, M.I., Dufau, C., Sutton, M., Stum, J., Lauret, O., Channelliere, C., 2013. Detection and variability of the Congo River plume from satellite derived sea surface temperature, salinity, ocean colour and sea level. Remote Sens. Environ. 139, 365-385. 
Hugues, H. J., Sondag, F., Cocquyt, C., Laraque, A., Pandi, A., André, L., Cardinal, D., 2011. Effect of seasonal biogenic silica variations on dissolved silicon fluxes and isotopic signatures in the Congo River. Limnol. Oceanogr. 556(2), 551-561.

Itambi, A.C., von Dobeneck, T. Adegbie, A.T., 2010. Millennial-scale precipitation changes over Central Africa during the late Quaternary and Holocene: evidence in sediments from the Gulf of Guinea. J. Quaternary Sci. 25(3), 267-279, doi:10.1002/jqs.1306.

Jahns, S., 1996. Vegetation history and climate changes in West Equatorial Africa during the Late Pleistocene and Holocene, based on a marine pollen diagram from the Congo fan. Veget. Hist. Archaeobot. 5, 207-213.

Jansen, J.H.F., 1990. Glacial-interglacial oceanography of the southeastern Atlantic Ocean and the paleoclimate of west central Africa. In Lanfranchi, R. \& Schwartz, D. (eds) Paysages quaternaires de l'Afrique centrale atlantique. ORSTOM, Paris, 110-123.

Jansen, J.H.F., Ufkes, E., Schneider, R.R., 1996. Late Quaternary movements of the AngolaBenguela-Front, SE Atlantic, and implications for advection in the equatorial ocean. In Wefer, G., Berger, W.H., Siedler, G., and Webb, D. (Eds.), The South Atlantic: Present and Past Circulation: Berlin (Springer-Verlag), 553-575.

Jansen, J.H.F., van Iperen, J.M., 1991. A 220,000-year climatic record for the East Equatorial Atlantic Ocean and Equatorial Africa: evidence from diatoms and opal phytolits in the Zaire (Congo) deep-sea fan. Paleoceanography 6, 573-591.

Lange, C.B., Tiffany, M.A., 2002. The diatom flora of the Salton Sea, California. Hydrobiologia 473, 179-201. 
Lisiecki, L.E., Raymo, M. E., 2005. A Pliocene-Pleistocene stack of 57 globally distributed benthic $\mathrm{d}^{18} \mathrm{O}$ records, Paleoceanography 20, PA1003, doi:10.1029/2004PA001071.

Lutjeharms, J.R.E., Meeuwis, J.M., 1987.The extent and variability of South-East Atlantic upwelling. In The Benguela and Comparable Ecosystems. Payne.A.1.L.,Gulland.J. A.and K.H.Brink (Eds). S. Afr. J. mar.Sci. 5, 51-62.

Marret, F., Kim, S.-Y., Scourse, J., 2013. A 30,000yr record of land-ocean interaction in the eastern Gulf of Guinea. Quatern. Res. 80(1), 1-8.

Marret, F., Scourse, J., Kennedy, H., Ufkes, E., Jansen, J.H.F., 2008. Marine production in the Congo-influenced SE Atlantic over the past 30,000 years: A novel dinoflagellate-cyst based transfer function approach. Mar. Micropaleontol. 68(1-2), 198-222.

Marret, F., Scourse, J., Versteegh, G., Jansen, J.H.F., Schneider, R., 2001, Integrated marine and terrestrial evidence for abrupt Congo River palaeodischarge fluctuations during the last deglaciation. J. Quat. Sci. 16, 761-766.

Materia, S., Gualdi, S., Navarra, A., Terray, L., 2012. The effect of Congo River freshwater discharge on Eastern Equatorial Atlantic climate variability. Clim. Dyn. 39(9-10), 2109-2125.

Meeuwis, J.M., Lutjeharms, J.R.E., 1990. Surface thermal characteristic of the AngolaBenguela front. Afr. J. Marine Sci. 9, 261-279.

Melia, M.B., 1984. The distribution and relationship between palynomorphs in aerosols a,d dee $^{\wedge}$-sea sediments ff the coast of nortwest Africa. Mar. Geol. 58, 345-371.

Mikkelsen, N., 1984. Diatoms in the Zaire deep-sea fan and Pleistocene palaeoclimatic trends in the Angola Basin and west equatorial Africa. Neth. J. Sea Res. 17, 280-292. 
Mikkelsen, N., 1997. Upper Quaternary diatoms on the Amazon Fan of the Western Atlantic. Proceedings of the Ocean Drilling Program, Scientific results 155, 367-373.

Moreno, J. L., Licea, S., Santoyo, H., 1996. Diatomeas del Golfo de California, Universidad Autonoma de Baja california Sur, Mexico, Mexico, 203, 34 pls.

Moreno-Ruiz, J.L., Licea, S., 1994. Observations on the valve morphology of Thalassionema nitzschoides (Grunow) Hustedt, in: Proceedings of the 13th Symposium on Living and Fossil Diatoms, edited by: Marino, D. and Montresov, M., Biopress Limited Publisher, Bristol, Maretea, Italy, 1-7 September, 1994, 393-413.

Nelson, D. M., Tréguer, P., Brezinski., M. A, Leynaert, A., Quéguiner, A., 1995. Production and dissolution of biogenic silica in the ocean: Revised global estimates, comparison with regional data and relationship to biogenic sedimentation. Glob. Biogeochem. Cycles 9, 359-372.

Pak, H., Zaneveld, J.R.V., Spinrad, R.W., 1984. Vertical distribution of suspended particulate matter in the Zaire river, estuary and plume. Neth. J. Sea Res. 17(2-4), 412-425.

Pokras, E.M., 1986. Preservation of fossil diatoms in Atlantic sediment cores: control by supply rate. Deep-Sea Research. 33(7), 893-902.

Pokras, E.M., Molfino, B., 1986. Oceanographic control of diatom abundances and species distributions in surface sediments of the tropical and southeast Atlantic. Mar. Micropaleontol. $10,165-188$.

Ragueneau, O., Tréguer, P., Leynaert, A., Anderson, R.F., Brzezinski, M.A., DeMaster, D.J., Dugdale, R.C., Dymond, J., Fischer, G., François, R., Heinze, C., Maier-Reimer, E., 
Martin-Jézéquel, V., Nelson, D.M., Quéguiner, B., 2000. A review of the Si cycle in the modern ocean: recent progress and missing gaps in the application of biogenic opal as a paleoproductivity proxy. Glob. Planet. Chang. 26, 317-365.

Ragueneau, O., Regaudie-de-Gioux, A., Moriceau, B., Gallinari, M., Vangriesheim, A., Baurand, F., Khripounoff, A., 2009. A benthic Si mass balance on the Congo margin: origin of the $4000 \mathrm{~m}$ DSi anomaly and implications for the transfer of Si from land to ocean. Deep-Sea Res. Part II 56 (23), 2197-2207.

Raimonet, M., Ragueneau, O., 2015. Rapid transport and high accumulation of amorphous silica in the congo deep-sea fan: A preliminary budget. J. Mar. Syst. 141, 71-79.

Rathburn, A. E., Deckker, P. D., 1997. Magnesium and strontium compositions of recent benthic foraminifera from the Coral Sea, Australia and Prydz Bay, Antarctica, Mar. Micropaleontol. 32, 231-248.

Rivera, P., Cruces, F., Avaria, S., 2006. Thalassionema bacillare (Heiden) Kolbe (Thalassionemataceae, Bacillariophyceae): Una especia ahora casi desconocida para las aguas chilenas pero comun en el fitoplancton costero de la zona norte. Ciencias y Tecnologias Marinas $9(1), 59-70$.

Romero, O. E., Crosta, X., Kim, J. H., Pichevin, L., Crespin, J., 2015. Rapid longitudinal migrations of the filament front off Namibia (SE Atlantic) during the past $70 \mathrm{kyr}$, Glob. Planet. Chang. $125,1-12$

Romero, O.E., Lange, C.B., Fischer, G., Treppke, U.F., Wefer, G., 1999. Variability in export production documented by downward fluxes and species composition of marine planktonic diatoms: observations from the tropical and equatorial Atlantic. In Fischer, G., and Wefer, G. 
(Eds.), Use of Proxies in Paleoceanography: Examples from the South Atlantic: Berlin (Springer-Verlag), 365-392.

Romero, O.E., Leduc, G., Vidal, L., Fischer, G., 2011. Millennial variability and long-term changes of the diatom production in the eastern equatorial Pacific during the last glacial cycle. Paleoceanography 26. http://dx.doi.org/10.1029/2010PA002099.

Romero, O.E., 2010. Changes in style and intensity of production in the Southeastern Atlantic over the last 70,000 yr. Mar. Micropaleontol. 74, 15-28.

Romero, O.E., Mohtadi, M., Helmke, P., Hebbeln, D., 2012. High interglacial diatom paleoproductivity in the western most Indo-Pacific Warm Pool during the past 130,000 years. Paleoceanography 27. http://dx.doi.org/10.1029/2012PA002299.

Romero, O.E., Boeckel, B., Donner, B., Lavik, G., Fischer, G., Wefer, G., 2002. Seasonal productivity dynamics in the pelagic central Benguela System inferred from the flux of carbonate and silicate organisms. J. Mar. Syst. 37, 259-278.

Romero, O.E., Armand, L.K., Crosta, X., Pichon, J.-J., 2005. The biogeography of major diatom taxa in Southern Ocean surface sediments: 3. Tropical/Subtropical species. Palaeogeogr. Palaeoclimatol. Palaeoecol. 223, 49-65.

Sancetta, C.D., 1982. Distribution of diatom species in surface sediments of the Bering and Okhotsk seas, micropaleont. 28, 221-257. 
Sar, E.A., Sunesen, I., Lavigne, A.S., 2010. Cymatotheca, Tryblioptychus, Skeletonema and Cyclotella (Thalassiosirales) from Argentinian coastal waters. Description of Cyclotella cubiculata sp. nov. Vie et Milieu 60(2), 135-156.

Savoye, B., Babonneau, N., Dennielou, B., Bez, M., 2009. Geological overview of the AngolaCongo margin, the Congo deep-sea fan and its submarine valleys. Deep-Sea Research II, 56, $2169-2182$

Schneider, R.R., Müller, P.J., Ruhland, G., 1995. Late Quaternary surface circulation in the east equatorial South Atlantic: evidence from alkenone sea surface temperatures. Paleoceanography 10, 197-219.

Schneider, R.R., Müller, P.J., Wefer, G., 1994. Late Quaternary paleoproductivity changes of the Congo deduced from stable carbon isotopes of planktonic foraminifera. Palaeogeogr. Palaeoclimatol. Palaeoecol. 110, 255-274.

Schneider, R.R., Price, B., Müller, P.J., Kroon, D., Alexander, I., 1997. Monsoon related variations in Zaire (Congo) sediment load and influence of fluvial silicate supply on marine productivity in the east equatorial Atlantic during the last 200,000 years. Paleoceanography 12 , $463-481$.

Schuette, G., Schrader, H., 1981. Diatom taphocoenoses in the coastal upwelling area off southwest Africa. Mar. Micropaleontol. 6, 131-155.

Servain, J., Picaut, J., Merle, J., 1982. Evidence of remote forcing in the Equatorial Atlantic Ocean. J.,phys. Oceanogr. 12, 457-463. 
Servant-Vildary, S., 1981. Etudes des diatomées et paléolimnologie du bassin tchadien au Cénozoïque Supérieur, Travaux et Documents de l'ORSTOM 84 (2 vol.), pp. 345.

Shannon, L.V., Boyd, A.J., Brundrit, G.B., Taunton-Clark, J., 1986. On the existence of an E1 Nino-type phenomenon in the Benguela system. J.Mar.Res. 44, 495-520.

Shannon, L.V., Nelson, G., 1996. The Benguela: large scale features and processes and system variability. In: Wefer, G., Berger, W.H., Siedler, G., Webb, D. (Eds). The South Atlantic Ocean, Present and Past Circulation, Springer, Berlin, pp.163-217.

Shi, N., Schneider, R.R., Beug, H.-J., Dupont L.M., 2001. Southeast trade wind varations during the last 135 kyr: evidence from pollen spectra in eastern South Atlantic sediments. Earth Planet. Sci. Lett. 17, 311-321.

Sholkovitz, E.R., Boyle, E.A., Price, N.N., 1978. The removal of dissolved humic Acids and Iron during Estuaring mixing. Earth Planet. Sci. Lett. 40, 130-136.

Sprintall, J., Tomczak, M,. 1992. Evidence of the barrier layer in the surface layer of the Tropics. J. Geophys. Res. Ocean 97(5),7305-7316.

Stuut, J.W., Pris, M.A., Schneider, R.R., Weltie, G.I., Jansen, JHF., Postma, G., 2002. A 300kyr record of aridity and wind strength in southwestern Africa: inferences from grain-size distributions of sediments on Walvis Ridge, SE Atlantic. Mar. Geology 180, 221-233.

Sundström, B. G., 1986. The marine diatom genus Rhizosolenia. A new approach to the taxonomy, Ph.D. Thesis, University of Lund, Sweden, pp. 116, 39 pls. 
Uliana, E., Lange, C.B., Donner, B., Wefer, G., 2001. Siliceous phytoplankton productivity fluctuations in the Congo Basin over the past 460,000 years: marine vs. riverine influence, ODP Site 1077. In: Wefer, G., Berger, W.H., Richter, C. (Eds.), Proc. ODP, Sci. Results, 175 (online). Available from World Wide Web: http://www-odp.tamu.edu/publications/ 175_SR/chap_11/chap_11.htm.

Uliana, E., Lange, C.B., Donner, B., Wefer, G., 2002. Evidence for Congo River freshwater load in Late Quaternary sediments of ODP Site $1077\left(5^{\circ} \mathrm{S}, 10^{\circ} \mathrm{E}\right)$. Palaeogeograph., Palaeoclimatol., Palaeoecol. 187, 137-150.

Van Bennekom, A.J., Berger, G.W., 1984. Hydrography and silica budget of the Angola Basin. Neth. J. Sea Res. 17, 149-200.

Van Bennekom, A.J., Jansen, J.H.F., Van der Gaast, S.J., Van Ieperen, J.M., Pieters, J., 1989. Aluminium-rich opal: An intermediate in the preservation of biogenic silica in the Zaire (Congo) deep-sea fan. Deep-Sea Res. 36, 173-190.

Van Cappellen, P., Qiu, L., 1997. Biogenic silica dissolution in sediments of the Southern Ocean: I. Solubility. Deep-Sea Res. 44(5), 1109-1128.

Van Iperen, J.M., van Weering, T.C.E., Jansen, J.H.F., van Bennekom, A.J., 1987. Diatoms in surface sediments of the Zaire deep-sea fan (SE Atlantic Ocean) and their relation to overlying water masses. Neth. J. Sea Res. 21, 203-217.

Vangriesheim, A., Pierre, C., Aminot, A., Metzi, N., Baurand, F., Caprais, J-C., 2009. The influence of the Congo river discharges in the surface and deep layers of the Gulf of Guinea. Deep-Sea Res. Part II. 56(23), 2197-2207. 
Voituriez, B., Herbland, A., 1981. The primary production in the Tropical Atlantic Ocean mapped from the oxygen values of Equalant 1 and 2 (1963). Bull. Mar. Sci. 31(4), 853-863.

Yankovsky, A. E., Chapman, D.C., 1997. A simple theory for the fate of buoyant coastal discharges, J.Phys. Oceanogr. 27, 1386- 1401.

Zabel, M., Schneider, R.R, Wagner, T., Adegbie, A.T, de Vries, U., Kolonic, S., 2001. Late Qutaernary climate changes in cenral Africa as inferred from terrigenous input t the Niger Fan. Quat. Res. 56, 207-217. 
Figure 1

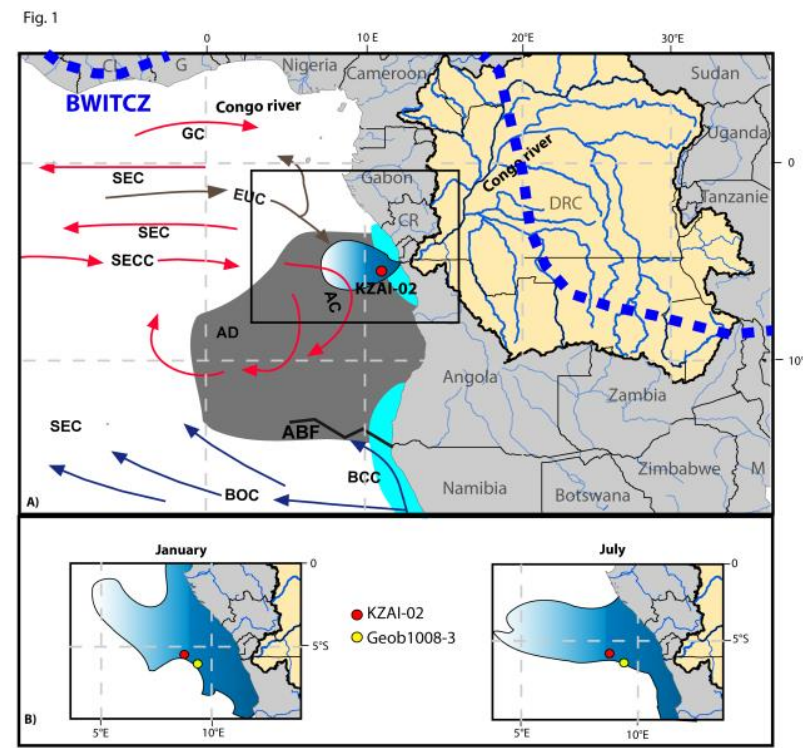


A)
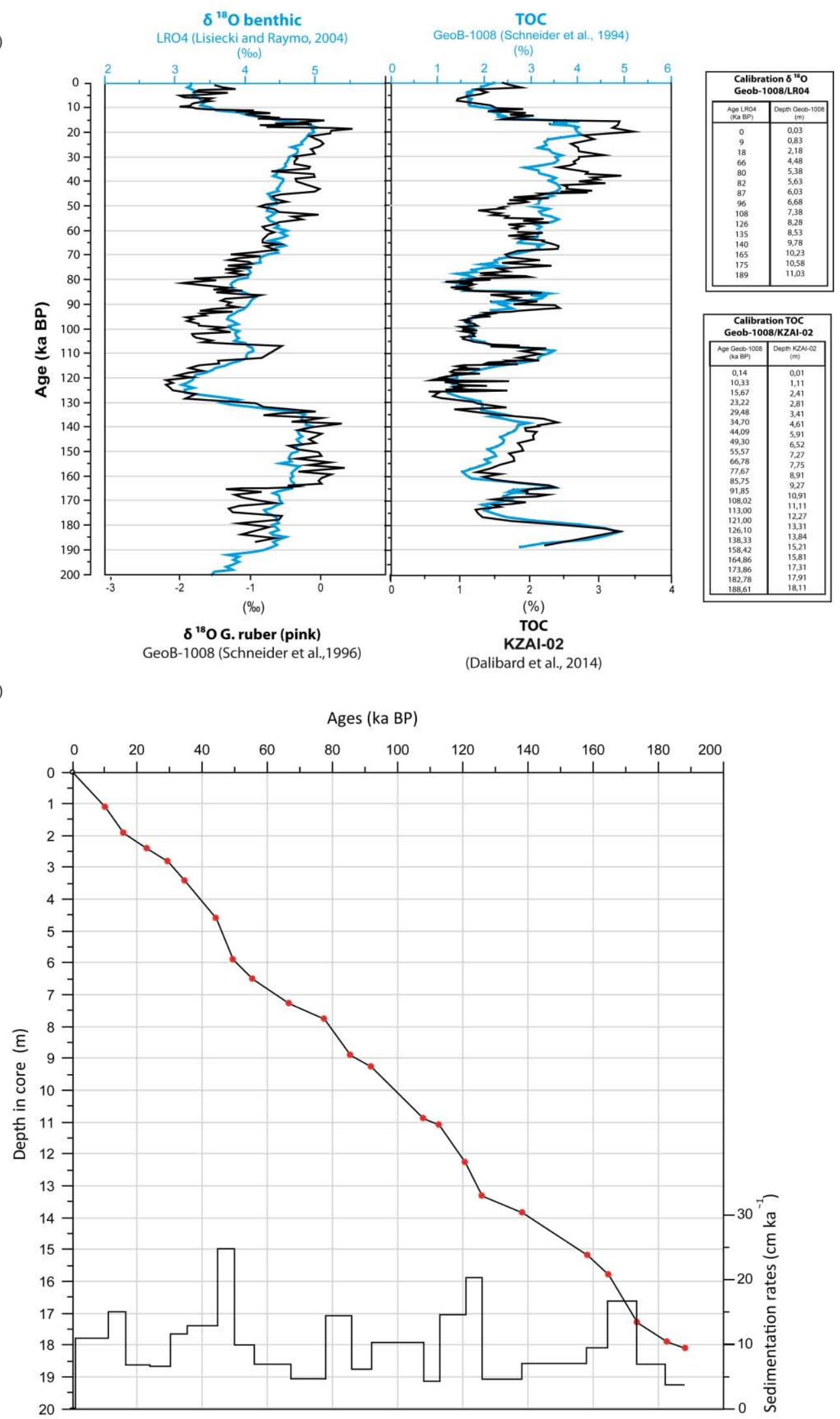
Fig. 3

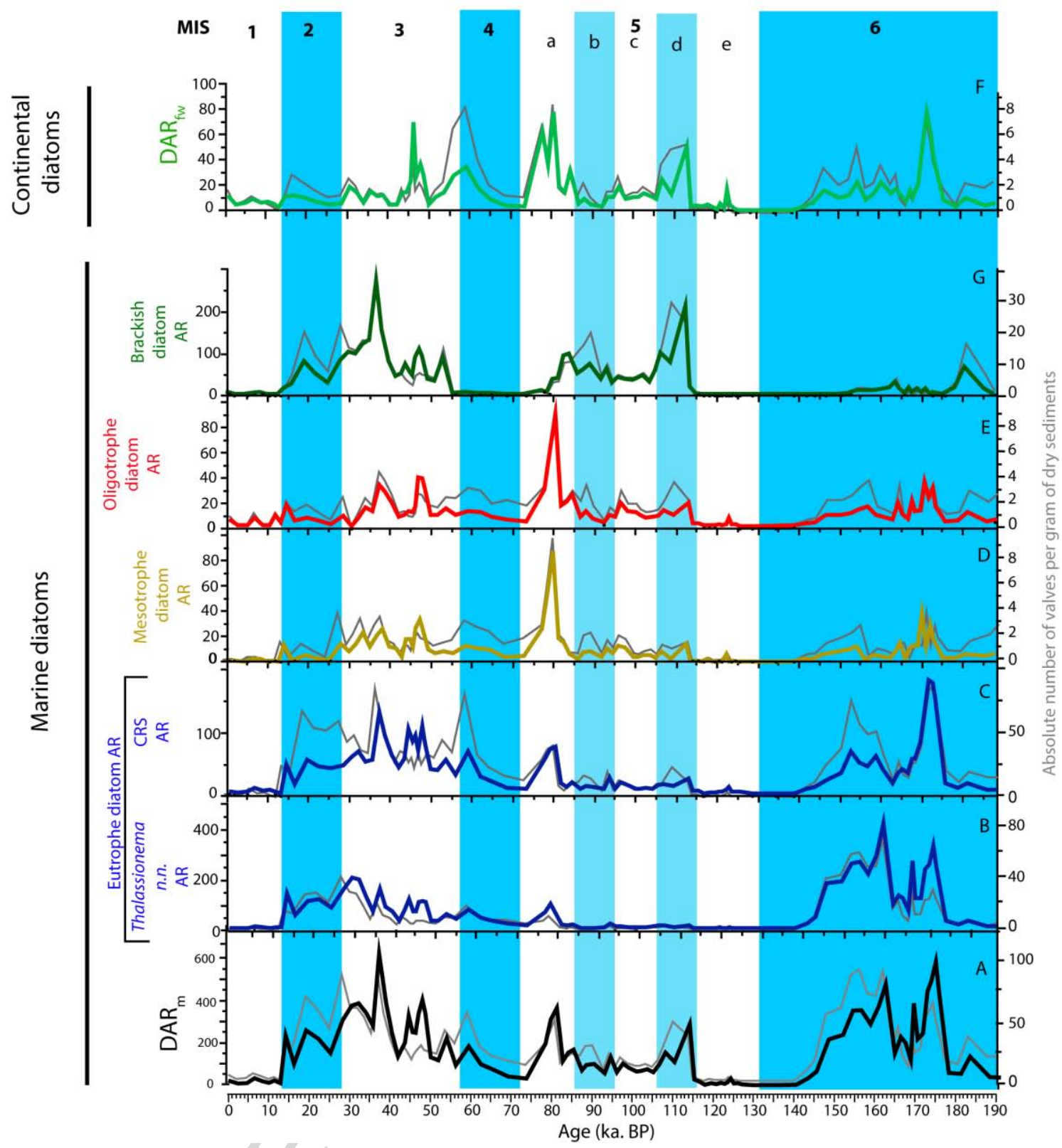


Fig. 4

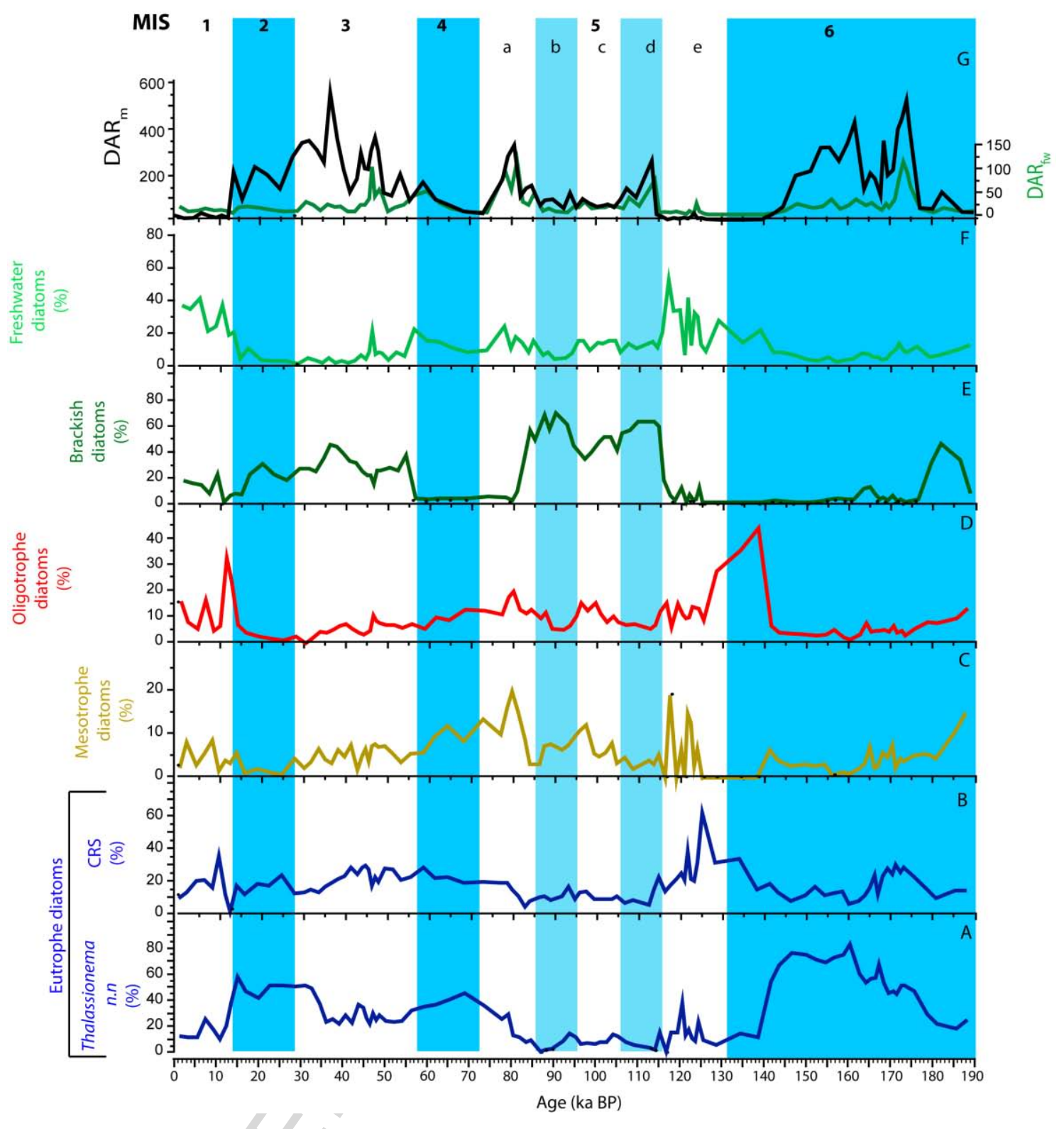



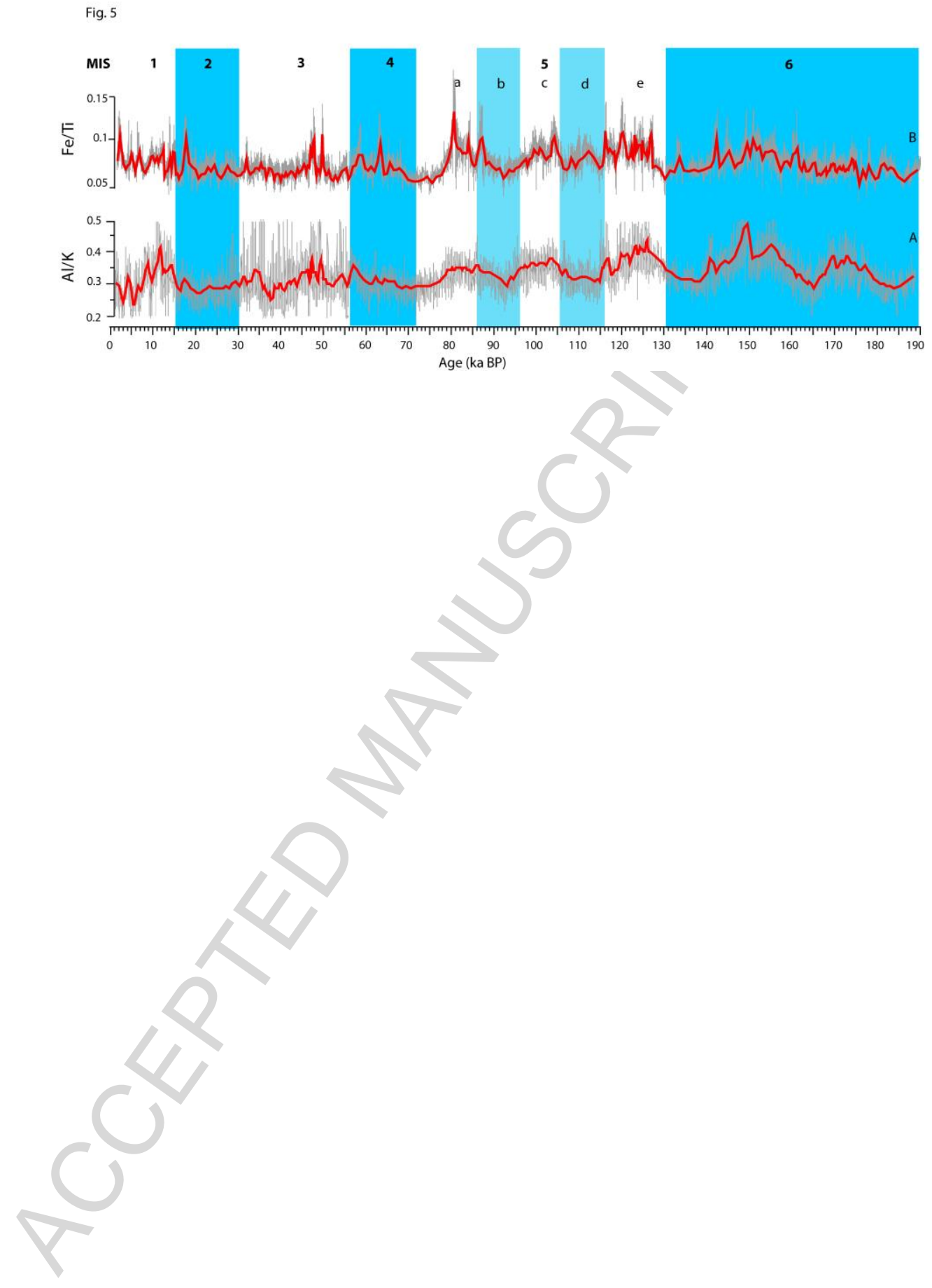
Fig. 6

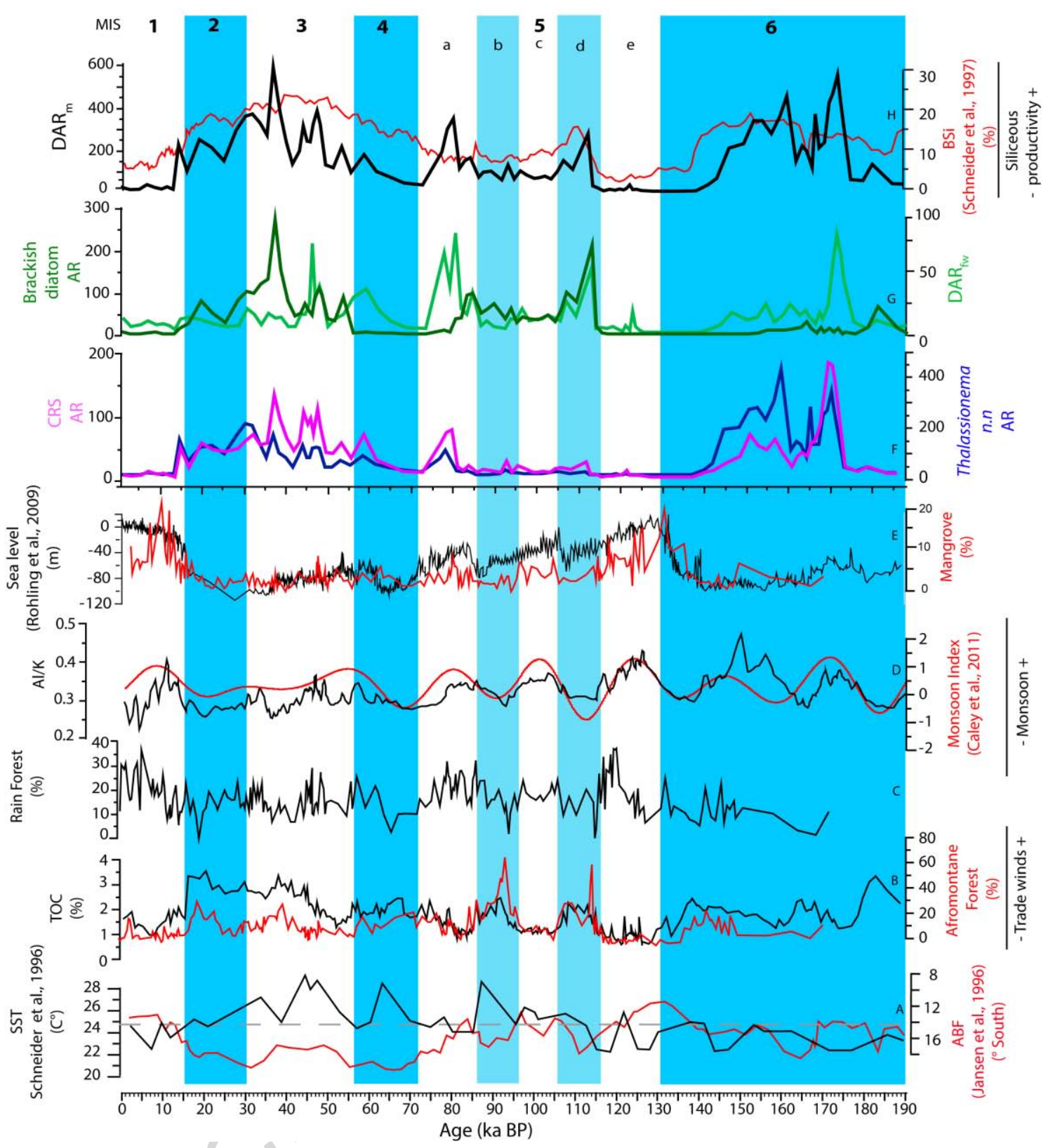




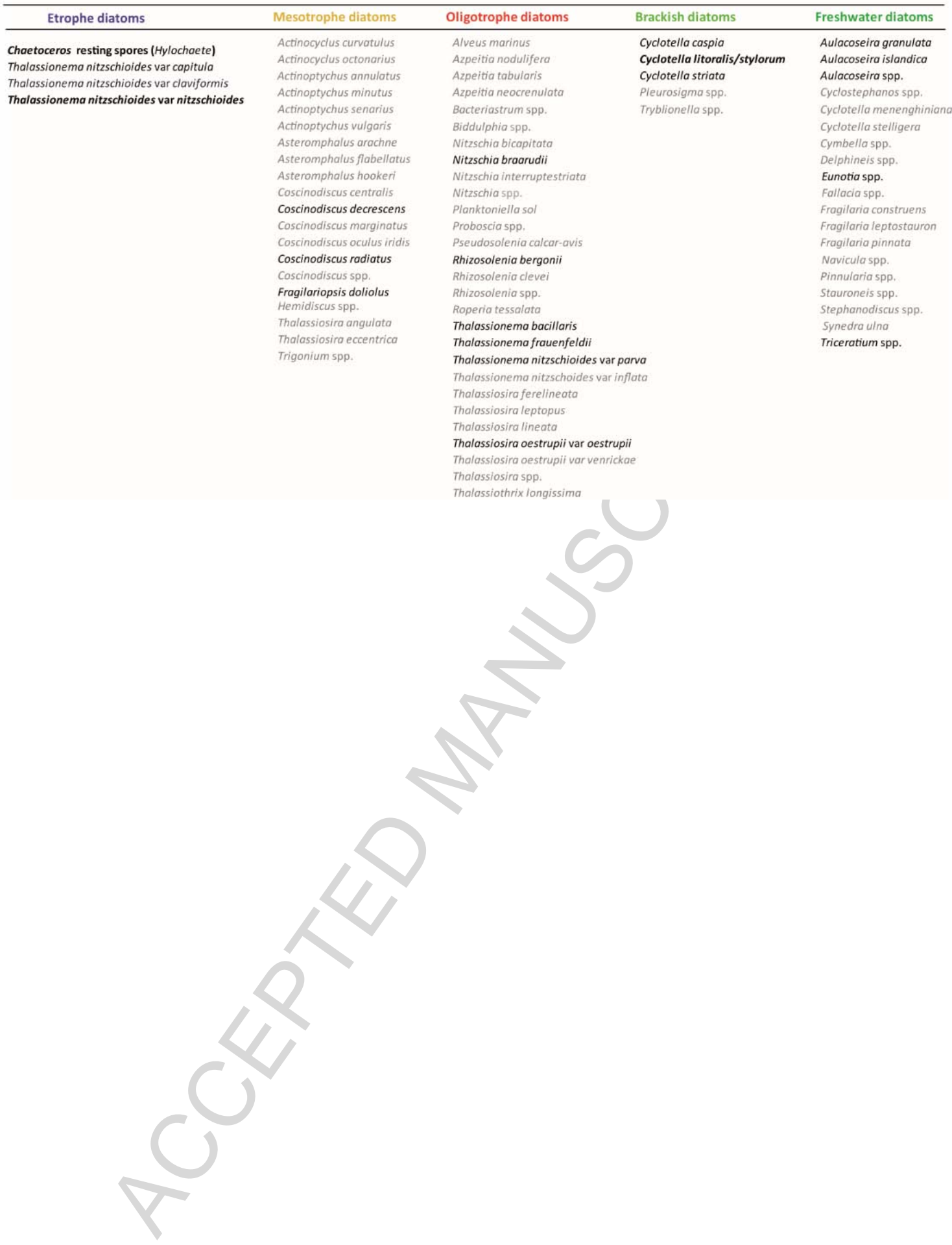


Table 1

Etrophe diatoms
Chaetoceros resting
spores (Hylochaete)
Thalassionema
nitzschioides var
capitula
Thalassionema
nitzschioides var
claviformis
Thalassionema
nitzschioides var
nitzschioides

\begin{tabular}{|c|c|}
\hline $\begin{array}{l}\text { Mesotrophe } \\
\text { diatoms } \\
\text { Actinocyclus } \\
\text { curvatulus }\end{array}$ & $\begin{array}{l}\begin{array}{l}\text { Oligotrophe } \\
\text { diatoms }\end{array} \\
\text { Alveus marinus }\end{array}$ \\
\hline $\begin{array}{l}\text { Actinocyclus } \\
\text { octonarius }\end{array}$ & Azpeitia nodulifera \\
\hline $\begin{array}{l}\text { Actinoptychu } \\
\text { s annulatus }\end{array}$ & Azpeitia tabularis \\
\hline $\begin{array}{l}\text { Actinoptychu } \\
\text { s minutus }\end{array}$ & $\begin{array}{l}\text { Azpeitia } \\
\text { neocrenulata }\end{array}$ \\
\hline
\end{tabular}

Actinoptychu

$s$ senarius

Actinoptychu

$s$ vulgaris

Asteromphal

us arachne

Asteromphal us flabellatus

Asteromphal us hookeri

Coscinodiscu s centralis Coscinodiscu $s$ decrescens Coscinodiscu $s$ marginatus Coscinodiscu s oculus iridis Coscinodiscu $s$ radiatus Coscinodiscu s spp.

Fragilariopsis

doliolus

Hemidiscus

spp.

Thalassiosira

angulata

Thalassiosira

eccentrica

Trigonium

spp. neocrenulata

Bacteriastrum spp.

Biddulphia spp.

Nitzschia bicapitata

Nitzschia braarudii

Nitzschia

interruptestriata

Nitzschia spp.

Planktoniella sol

Proboscia spp.

Pseudosolenia

calcar-avis

Rhizosolenia

bergonii

Rhizosolenia clevei

Rhizosolenia spp.

Roperia tessalata

Thalassionema

bacillaris

Thalassionema

frauenfeldii

Thalassionema

nitzschioides var

parva

Thalassionema

nitzschoides var

\section{Brackish \\ Freshwater \\ diatoms diatoms \\ Cyclotella \\ caspia \\ Aulacoseira \\ Cyclotella \\ litoralis/stylor Aulacoseira \\ um \\ islandica}

$\begin{array}{ll}\begin{array}{l}\text { Cyclotella } \\ \text { striata }\end{array} & \begin{array}{l}\text { Aulacoseira } \\ \text { spp. }\end{array} \\ \text { Pleurosigma } & \text { Cyclostephan } \\ \text { spp. } & \text { os spp. } \\ & \text { Cyclotella } \\ \text { Tryblionella } & \text { menenghinia } \\ \text { spp. } & \text { na } \\ & \text { Cyclotella } \\ & \text { stelligera } \\ & \text { Cymbella } \\ & \text { spp. } \\ & \text { Delphineis } \\ & \text { spp. }\end{array}$

Eunotia spp.

Fallacia spp.

Fragilaria

construens

Fragilaria

leptostauron

Fragilaria

pinnata

Navicula

spp.

Pinnularia

spp.

Stauroneis

spp.

Stephanodisc

us spp.

Synedra ulna

Triceratium

spp. 
inflata

Thalassiosira

ferelineata

Thalassiosira

leptopus

Thalassiosira

lineata

Thalassiosira

oestrupii var

oestrupii

Thalassiosira

oestrupii var

venrickae

Thalassiosira spp.

Thalassiothrix

longissima 
Figure captions

Figure 1. (A) General map of central Africa and Angola Basin in southeastern equatorial Atlantic Ocean, showing the course of the Congo River, its main distributaries and its drainage area (watershed), the surface and subsurface currents (GC: Guinea current; SEC: South Equatorial current; EUC: Equatorial Under Current; AC: Angola Current; SECC: South Equatorial Counter Current; BOC: Benguela Oceanic Current; BCC: Benguela Coastal Current. Red arrows: warm currents; blue arrows: cold currents and grey arrows: under currents), and highly productive areas 861 (Blue surface: Coastal upwelling; Grey surface: Oceanic upwelling; modified from Schneider et al., 1994). Position of the boreal winter ITCZ (blue dashed line) while the boreal winter ITCZ is located around $15-20^{\circ} \mathrm{N}$, out of the figure. Country names (Grey) (CI: Côte d'Ivoire; CR: Congo Republic; DRC: Democratic Republic of the Congo; G: Ghana; M: Malawi). (B) Core location with the position and surface of the Congo River plume during January and July (modified from Hopkins et al., 2013).

Figure 2. Age model of core KZAI-02 based on (A) the correlation of core GeoB 1008-3 G. ruber (pink) in (Schneider et al., 1994) to the LR04 reference stack (Lisiecki \& Raymo, 2005) and the correlation of core KZAI-02 TOC record (Dalibard et al., 2014) to core GeoB 1008-3 TOC record (Schneider et al., 1994). Pointers for each correlation are noted on the right side of the plots (B) Resulting ages (ka BP) versus depth (m) in core KZAI-02 (black curve with red dots) and sedimentation rates (black squared line). The line depicts the linear interpolation between two consecutive pointers (red dots).

Figure 3. Accumulation rates of diatom in $x 10^{6} \cdot \mathrm{cm}^{-2} \cdot \mathrm{ka}^{-1}$ and absolute abundances of diatom valves in millions $\left(\mathrm{x} 10^{6}\right)$ per gram of dry sediments (Grey line) in core KZAI-02 versus age . (A) For total marine diatoms $\left(\mathrm{DAR}_{\mathrm{m}}\right)$; (B) for Thalassionema nitzschioides var. nitzchioides; (C) for Chaetoceros (Hyalochaete) resting spores (CRS); (D) for Mesotrophe diatoms; (E) for 
Oligotrophe diatoms; (F) for Brackish diatoms; $(\mathrm{G})$ for Freshwater diatoms $\left(\mathrm{DAR}_{\mathrm{fw}}\right)$. Diatoms species included in each group are detailed in Appendix 1.

Figure. 4. Relative abundance of diatoms in core KZAI-02 versus age. (A) Thalassionema nitzschioides var nitzchioides; (B) Chaetoceros (Hyalochaete) resting spores (CRS); (C) Mesotrophe diatoms; (D) Oligotrophe diatoms; (E) Brackish diatoms; (F) Freshwater diatoms; (G) Total marine $\left(\mathrm{DAR}_{\mathrm{m}}\right)\left(\mathrm{Black}\right.$ line) and Freshwater $\left(\mathrm{DAR}_{\mathrm{fw}}\right)$ (Green line) accumulation rates of diatom in $\mathrm{x} 10^{6} \cdot \mathrm{cm}^{-2} \cdot \mathrm{ka}^{-1}$.

Figure 5. Records of (A) Al/K -ratio and (B) Fe/Ti-ratio in core KZAI-02 versus age. Raw data are represented by the thin grey lines while the 20 points running averages are represented by the thick red lines.

Figure 6. Comparison of diatom accumulation rates, total organic carbon (TOC) and Al/K ratio in core KZAI-02 with climate proxies from Equatorial Africa. (A) SST estimates obtained on GeoB 1008-3 (Schneider et al., 1996) and ABF latitudinal position (Jansen et al., 1996) (red line); (B) TOC values (black line) and relative abundance of afromontane pollens (red line) in core KZAI-02 (Dalibard et al., 2014); (C) Relative abundance of rainforest pollen in core KZAI02 (Dalibard et al., 2014); (D) Monsoon Index (red line) (Caley et al., 2011) and KZAI-02 Al/K ratio (black line); (E) Sea level variations (Rohling et al., 2009) and relative abundance of mangrove pollens (red line) in core KZAI-02; (F) AR of the Brackish and Freshwater groups; (G) AR of CRS and Thalassionema nitzschioides var nitzschioides; (H) DAR in core KZAI-02 (black line) and BSi content (red line) measured in core GeoB1008-3 (Schneider et al., 1997).

Appendix. 1. List of diatom species or group of species included in the different groups. Species and groups of species that represents more than $10 \%$ of the total assemblage are in bold. Species and groups of species that represent between 1 and $10 \%$ of the assemblage are in black and species and groups of species that represent less than $1 \%$ of the total assemblage are in grey. 


\section{Highlights}

- Siliceous productivity resulted from complex combinations of climatic and oceanic forcing.

- DSi input from the Congo River is essential for high diatom productivity.

- highest Congo River discharge had a negative impact on diatom productivity.

- It isn't possible using freshwater diatoms to track River discharge evolutions. 